\title{
Isolation and individual electrical stimulation of single smooth-muscle cells from the urinary bladder of the pig
}

\author{
J. J. GLERUM, R. VAN MASTRIGT, J. C. ROMIJN and D. J. GRIFFITHS \\ Department of Urology and Department of Biomedical Physics and Technology, Erasmus University Rotterdam, The Netherlands
}

Received 28 May 1986 and in revised form 10 September 1986

\begin{abstract}
Summary
In contrast to striated muscle, measurements on strips of smooth muscle cannot be uniquely interpreted in terms of an array of contractile units. Therefore scaling down to the single-cell level is necessary to gain detailed understanding of the contractile process in this type of muscle. The present study describes the development of a method for isolating contractile single smooth muscle cells from pig urinary bladders. Contractile responses evoked by individual electrical stimulation were used as a measure of cell quality during development of the method. Responses were evaluated by measuring latency, contraction and relaxation times, as indicated by visible length changes, and stored on-line in a computer. Initial length, relative shortening and shortening speed were determined by measuring cell lengths in previously timed still video frames using a computer-controlled crosshair device. Increase of stimulus pulse duration resulted in improved responses, indicating that the observed shortening represented a physiological contractile response. Ultimately this method of evaluation was applied to two sets of cell preparations obtained by two different methods, one using only collagenase digestion, the other using mechanical manipulation as well. Both sets showed two main patterns of response to electrical stimulation: a pattern of contraction upon stimulation followed by enhanced contraction when stimulation was switched off (CK), and a pattern of contraction upon stimulation followed by relaxation when the stimulus was switched off (CR).

The set of preparations containing the highest percentage of CR cells was found to be superior (i.e. greater initial length, shorter latency and contraction times, increased shortening and higher shortening speed). The method of isolation used for this set gives a high yield of contractile cells available for experimental use over a long span of time.
\end{abstract}

\section{Introduction}

Much research has been done on the contractility of skeletal and heart muscle. More recently smooth muscle and its contractile properties have become a field of interest (Murphy, 1976; Hellstrand, 1979; Van Mastrigt \& Griffiths, 1979). As yet, however, little is known about the basic contractile units of the smooth muscle of specific human organs. In the field of urology, all knowledge of bladder contractility has been deduced from in vitro experiments on bladder strips (Van Mastrigt \& Glerum, 1985; Van Mastrigt \& Griffiths, 1986). Since, in contast to skeletal muscle, the organization of, and the interaction between, the smallest contractile units in smooth muscle is not immediately evident, it is impossible to interpret the measurements uniquely in terms of such units (Meiss, 1975; van Duyl, 1985). The scaling down of experiments to the single-cell level thus seems inevitable (Fay et al., 1976; Fay, 1977). Experiments on single cells are promising because unwanted and/or unknown influences from neighbouring cells, connective tissue elements such as collagen and elastin, innervation and vascularization can be avoided, so making it possible to carry out very direct mechanic- al, pharmacological and electrophysiological experiments. It is expected that these experiments will open up new and interesting ways of evaluating biopsies from smooth-muscle organs such as the human bladder.

In the present study a method is described for obtaining viable, contractile, single smooth-muscle cells from pig bladders. Pig bladders were chosen, because they proved both anatomically and mechanically to be a good model of the human bladder (Douglas, 1972) and are easily obtainable. To evaluate the quality of the cells isolated using this empirically designed method, electrical stimulation experiments were performed; in which initial length, latency, contraction time, percentage shortening and unstrained speed of shortening were measured. The effects of variations in stimulus parameters were also investigated (Van Mastrigt \& Glerum, 1985).

\section{Material and methods}

Pig bladders were collected from the local abattoir approximately 15 minutes after slaughter. After opening 
and emptying, two or three pieces measuring about $2 \times$ $3 \mathrm{~cm}$ were cut out of the anterior wall, immersed in cold ( $4^{\circ} \mathrm{C}$, pH 7.35) Krebs-Hepes buffer (fluid B, see Appendix, Table 1) in an insulated vessel and transported to the laboratory.

Krebs-Hepes buffer is a modification of the original Krebs buffer (fluid A). To ensure adequate buffering without gas bubbling, Hepes was added to fluid A (the stock solution) and volume corrections were made so as to restore the correct osmolarity.

Approximately $1 \mathrm{~h}$ after death of the animal, one of the strips was taken out and pinned to the bottom of a shallow container in preoxygenated $\left(95 \% \quad \mathrm{O}_{2} / 5 \% \quad \mathrm{CO}_{2}\right)$ KrebsHepes buffer (fluid B) at room temperature and its mucosa was carefully stripped away. About 25 pieces of muscle of about $2 \times 4 \mathrm{~mm}$ were cut and immediately immersed in $4 \mathrm{ml}$ of fluid B, contained in a $60 \mathrm{~mm}$ Petri dish. They were minced carefully with scissors until the largest dimension was about $1.5 \mathrm{~mm}$. The collagenase and other constituents of the isolation solution (see Appendix, Table 2) were dissolved in $6 \mathrm{ml}$ of fluid $B$ and added to the contents of the Petri dish.

The complete contents were poured into a plastic vessel of diameter $65 \mathrm{~mm}$, containing a magnetic stirring rod of length $15 \mathrm{~mm}$. The lid was tightly closed and the vessel was placed in a heated $\left(37^{\circ} \mathrm{C}\right)$ water bath and stirred at 1 to 2 rev. $\mathrm{s}^{-1}$ for $50 \mathrm{~min}$ (phase 1). Next $10 \mathrm{mg}$ of DNAase, dissolved in $2 \mathrm{ml}$ of fluid $\mathrm{B}$, was added and stirring was continued for another $15 \mathrm{~min}$ (phase 2). Following this incubation period, $6 \mathrm{ml}$ of MEM containing $10 \% \mathrm{FCS}$ (fluid C), was added to the cell suspension.

The cell suspension was filtered with a $400 \mu \mathrm{m}$ Cellector tissue sieve, after which the flocculent remnants were resuspended in fluid $D$, preoxygenated with $95 \% \mathrm{O}_{2} / 5 \%$ $\mathrm{CO}_{2}$. The filtrate was divided into three portions which were centrifuged at $1000 \mathrm{rev} . \min ^{-1}$ for $5 \mathrm{~min}$. After centrifugation the supernatant was sucked away with a narrow-bore Pasteur pipette and the sediment was carefully resuspended in $3 \mathrm{ml}$ of fluid $D$. This preparation is referred to as Fraction I.

Fraction II was prepared mechanically from the resuspended flocculent remnants, by sucking in and blowing out the partly digested tissue pieces through a series of specially made pipettes with successively smaller internal diameters in the range 5.0 to $0.5 \mathrm{~mm}$, so as to loosen partly attached cells, continuing until the suspension became clearly opalescent. The remaining tissue parts were then sieved out with a $400 \mu \mathrm{m}$ sieve, the filtrate thus forming Fraction II. Fraction II was immediately used for experiments, whilst Fraction I was kept in a vibration-free refrigerator for 6 to $8 \mathrm{~h}$.

For the incubation of the cells during the electrical stimulation experiments, a modified version of a $35 \mathrm{~mm}$ culture dish incubator (Ince et al., 1983) with built-in temperature regulation was used, mounted on a Zeiss IM inverted microscope. Temperature was kept at $37.0 \pm$ $0.1^{\circ} \mathrm{C}$. The atmosphere above the preparation, immersed in fluid $\mathrm{D}$, was kept at approximately $\mathrm{pO}_{2} 150 \mathrm{mmHg}$ and $p \mathrm{CO}_{2} 38 \mathrm{mmHg}$ by gently blowing an air $/ 5 \% \mathrm{CO}_{2}$ mixture over the fluid surface, so as to provide proper equilibration. Thus a $\mathrm{pH}$ of 7.35 was attained. To prevent evaporation a thin layer of Klearol was spread over the fluid surface (Van
Dijk et al., 1984). Prior to the electrical stimulation experiments cells were left for $1 \mathrm{~h}$ to accommodate and settle on the bottom of the culture dish. All procedures were conducted as far as possible aseptically to prevent bacterial contamination.

Electrical stimulation was performed using a $50 \mu \mathrm{m}$ platinum wire electrode, drawn into a glass micropipette, which was mounted on a motor-driven micromanipulator. A $1 \mathrm{~mm}$ diameter silver wire lying on the bottom near the side of the culture dish was used as an earth electrode.

In each experiment 48 structures presumed to be smooth muscle cells were stimulated individually, by placing the micro-electrode near the chosen cell and applying an electrical pulse train until a few seconds after maximum shortening had been attained. Cells were picked out randomly over the whole bottom surface of the culture dish. The cell concentration was kept low so as to allow individual stimulation.

Stimulation pulses of $1.8 \mathrm{~V}$ amplitude and 5.0, 10.0 or $15.0 \mathrm{~ms}$ duration, and with a repetition frequency of $50.0 \mathrm{~Hz}$, were generated by a standard pulse generator and amplified by a Kepco operational power amplifier. The pulse train was switched on and off by a relay controlled by a push button.

A black and white video camera was mounted via a beam-splitting device upon the IM microscope. Microscope and micromanipulator were placed upon a vibrationdamped table. The video camera was driven by sync signals from the video-monitor output of a DEC PC 350 computer. The video signals from the computer and the camera were mixed and displayed on a high-resolution black and white monitor and recorded on a U-matic video recorder. The computer displayed a real-time clock, an event-marker clock and stimulus on/off and event-marker indicators, as well as additional information about the preparation and stimulus parameters in use.

The indicators were controlled by the stimulus control relay and by push buttons, which were depressed at the beginning and end of contraction and relaxation of the cell under observation. The times of activation of the indicators were stored on-line in pairs of records, one pair for each contraction-relaxation cycle and up to 48 pairs in one experiment file. Whenever a cell responded properly to electrical stimulation and timing was considered to be accurate, a quality character was added to the record pair.

Following the experiments measurements of length and calculations of length change and contraction velocity were performed off-line in still video frames, using a specially developed computer-controlled cross-hair device (Glerum et al., 1986). By taking the exact frames in which the chosen events had been timed, the lengths before, during and after contraction and relaxation were measured. The measured values, together with one character describing the reaction pattern of the cell during stimulation and one character describing the pattern after switching off the stimulus, were added to the corresponding record pairs, which in this way ultimately contained experiment number, day, time, stimulus on and off times, start and end of contraction times, start and end of relaxation times, initial length, length at maximum contraction, length before relaxation and length at maximum relaxation and a character pair describing the reaction pattern of a specific cell. 
The data obtained in this way were placed in groups corresponding to the reaction patterns found and to the various fractions and the different stimulus parameters used. Initially analysis of variance was performed in order to judge whether data from separate experiments could be combined, but as not all groups of data showed a normal distribution, further tests were performed nonparametrically. Thus correlations were investigated using Spearman's rank correlation coefficient and differences between groups were tested for significance by the Mann-Whitney U test. A significance level of 0.05 was used in all cases.

\section{Results}

In order to investigate the contractile responses quantitatively, 23 electrical stimulation experiments were performed on 13 preparations from eight successive isolation procedures. Each experiment consisted of 48 attempts to stimulate a cell individually, a different cell being used for every attempt. After every isolation Fraction II was tested for contractile behaviour with $10.0,5.0$ or $15.0 \mathrm{~ms}$ pulses. In five cases Fraction I, which had been stored in the refrigerator during the Fraction II tests, was tested with $10.0 \mathrm{~ms}$ pulses, once followed by a test with $5.0 \mathrm{~ms}$ pulses and once followed by a test with $15.0 \mathrm{~ms}$ pulses. Thus in total 1104 structures resembling smooth muscle cells were individually tested for a contractile response to electrical stimulation. A typical example of a cell from Fraction I before, during and after stimulation is shown in Figs 1a-1c.

The appearance of the smooth-muscle cells ranged from rather short $(80-150 \mu \mathrm{m})$ cigar-shaped bodies with variable diameters $(10-20 \mu \mathrm{m})$ to long $(150-350$ $\mu \mathrm{m}$ ) more thread-like (approx. $10 \mu \mathrm{m}$ wide) structures. In phase contrast the shorter cells displayed more contrast relative to the background than the longer cells. Some of the longer cells showed fine longitudinal striation. The shorter cells more often had irregularities in the shape of the cell wall (invaginations, evaginations, bends, etc.) than did the longer cells, but these features were not

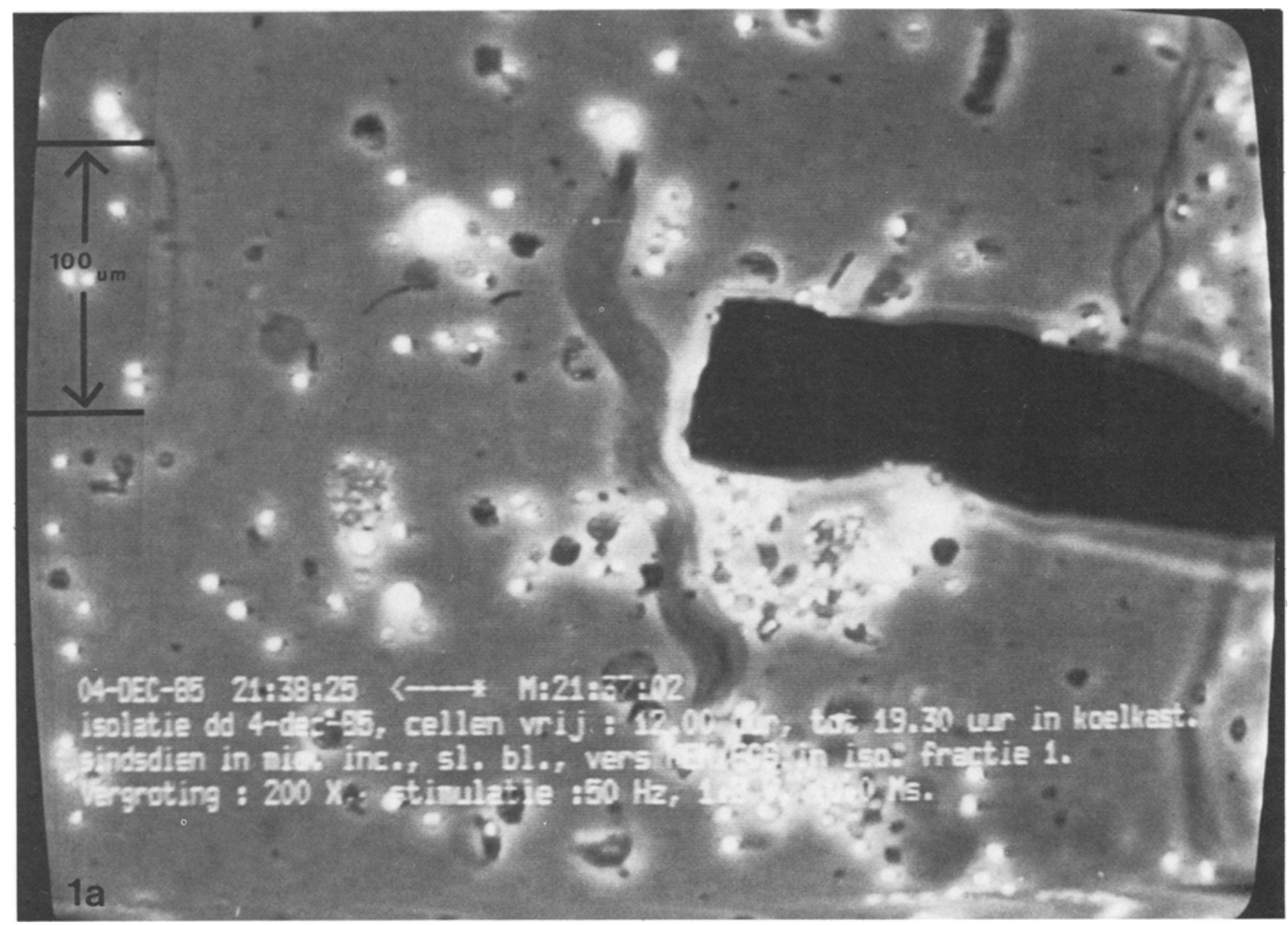

Fig. 1. Typical example of a single smooth muscle cell, from Fraction I, isolated from the bladder of the pig: (a) before, (b) during and (c) after electrical stimulation with a train of pulses of $10.0 \mathrm{~ms}$ duration and $1.8 \mathrm{~V}$ amplitude at a repetition frequency of $50.0 \mathrm{~Hz}$. Photographs were made from a mixed video display of the phase contrast microscope image and the computer screen. The stimulation electrode $(50 \mu \mathrm{m}$ platinum wire) can be seen in the right half of each picture. 

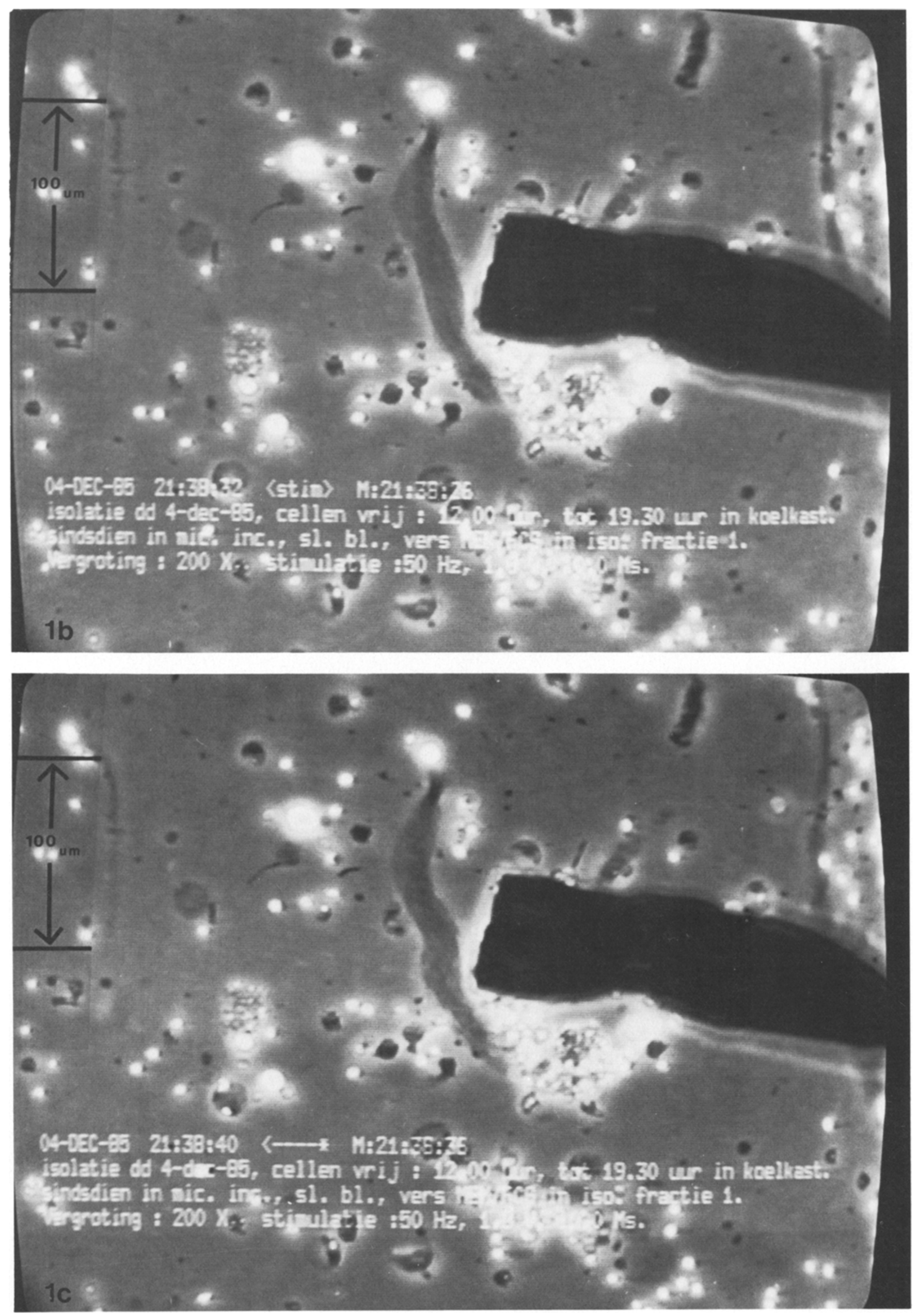
Table 1. The major constituents of the fluids used during transport, cell isolation and electrical stimulation.

\begin{tabular}{|c|c|c|c|c|}
\hline $\begin{array}{l}\text { Constituent ions and } \\
\text { molecules }\end{array}$ & $\begin{array}{l}\text { Fluid A } \\
\text { (Krebs buffer) } \\
\left.\text { (mmol litre }^{-1}\right)\end{array}$ & $\begin{array}{l}\text { Fluid B } \\
\text { (Krebs-Hepes } \\
\text { buffer) } \\
\text { (mmol litre }^{-1} \text { ) }\end{array}$ & $\begin{array}{l}\text { Fluid C } \\
(M E M+10 \% \\
\text { FCS }) \\
\left.\text { (mmol litre }^{-1}\right)\end{array}$ & $\begin{array}{l}\text { Fluid } D \\
(2 / 3 \mathrm{~B}+1 / 3 \mathrm{C}) \\
\left(\mathrm{mmol} \text { litre }{ }^{-1}\right)\end{array}$ \\
\hline $\mathrm{NaCl}$ & 118.0 & 104.8 & 116.3 & 108.6 \\
\hline $\mathrm{KCl}$ & 4.7 & 4.2 & 5.4 & 4.6 \\
\hline $\mathrm{NaHCO}_{3}$ & 25.0 & 22.2 & 26.2 & 23.5 \\
\hline $\mathrm{KH}_{2} \mathrm{PO}_{4}$ & 1.2 & 1.1 & - & 0.7 \\
\hline $\mathrm{NaH}_{2} \mathrm{PO}_{4}$ & - & - & 1.0 & 0.3 \\
\hline $\mathrm{CaCl}_{2}$ & 1.8 & 1.6 & 1.8 & 1.7 \\
\hline $\mathrm{MgSO}_{4}$ & 1.2 & 1.1 & 0.8 & 1.0 \\
\hline D-Glucose & 11.0 & 9.8 & 5.6 & 8.4 \\
\hline Hepes & - & 22.2 & - & 14.8 \\
\hline $\mathrm{NaOH}$ & - & 13.3 & - & 8.9 \\
\hline Osmolarity (mOsmo & 316.6 & 316.6 & $310.4^{*}$ & $314.5^{*}$ \\
\hline
\end{tabular}

The Krebs-Hepes buffer is made out of stock solution A by adding $25 \mathrm{mmol}$ Hepes per litre, adjusting the $\mathrm{pH}$ to 7.35 with $1 \mathrm{mmol}$ litre ${ }^{-1} \mathrm{NaOH}$ and correcting the osmolarity by addition of distilled water to a total volume of 1.126:1. Fluid D is the result of adding one part of fluid $C$ to two parts of fluid B. *The non-listed organic constituents of MEM were not taken into account in calculating the osmolarity. Measurements of osmolarity showed only minor differences from the calculated values.

Ta'ble 2. The constituents, with their respective concentrations, of the isolation solutions used in the first and second phases of the enzymatic incubation period.

\begin{tabular}{|c|c|c|c|c|}
\hline \multirow[t]{3}{*}{$\because$} & \multicolumn{4}{|c|}{ Concentration in fluid $B$} \\
\hline & \multicolumn{2}{|c|}{$\begin{array}{l}\text { Phase } 1 \text { isolation } \\
\text { solution }\end{array}$} & \multicolumn{2}{|c|}{$\begin{array}{l}\text { Phase } 2 \text { isolation } \\
\text { solution }\end{array}$} \\
\hline & $\left(\mathrm{mg} 10 \mathrm{ml}^{-1}\right)$ & $(\%)$ & $\left(\mathrm{mg} 10 \mathrm{ml}^{-1}\right)$ & $(\%)$ \\
\hline Albumin fraction 5 & 100 & 10.0 & 83.3 & 8.3 \\
\hline Antitrypsin II-O & 60 & 6.0 & 50 & 5.0 \\
\hline Collagenase CLS IV & 30 & 3.0 & 25 & 2.5 \\
\hline DNAase DN-25 & - & - & 8.3 & 0.8 \\
\hline
\end{tabular}

The solution for phase 1 is made by dissolving albumin, antitrypsin and collagenase in $6 \mathrm{ml}$ of Krebs-Hepes buffer and adding this to $4 \mathrm{ml}$ of the same fluid containing the minced tissue. The phase 2 solution is obtained by adding $10 \mathrm{mg}$ of DNAase dissolved in $2 \mathrm{ml}$ of Krebs-Hepes buffer to the phase 1 solution.

consistently observed in a particular phase of the contraction cycle and also appeared in the resting state in varying degrees.

The two most frequently observed patterns of response were contraction upon electrical stimulation, followed by an enhanced contraction when the stimulus was switched off (code CK), and contraction upon electrical stimulation, followed by relaxation when the stimulus was switched off (code CR). Other, less frequently observed patterns were irreversible contraction into a globular form, loss of cell contents during contraction and explosion during the course of contraction.

Table 3 shows the total number of cells stimulated in both fractions and their distribution over the main types of reaction patterns. 
Table 3. Numbers and percentages of smooth-muscle cells in two differently isolated fractions, showing various types of reactions upon individual electrical stimulation.

\begin{tabular}{|c|c|c|c|c|c|c|c|c|c|}
\hline & \multirow{2}{*}{$\begin{array}{l}\text { Total } \\
\text { number of } \\
\text { attempts } \\
(n)\end{array}$} & \multicolumn{2}{|c|}{$\begin{array}{l}\text { CK } \\
\text { pattern }\end{array}$} & \multicolumn{2}{|c|}{$\begin{array}{l}C R \\
\text { pattern }\end{array}$} & \multicolumn{2}{|c|}{$\begin{array}{l}\text { Miscellaneous } \\
\text { patterns }\end{array}$} & \multicolumn{2}{|c|}{$\begin{array}{l}\text { Shortening, } \\
\text { but by less } \\
\text { than } 5 \% \text { of } \\
\text { initial length }\end{array}$} \\
\hline & & $(n)$ & $(\%)$ & $(n)$ & $(\%)$ & $(n)$ & $(\%)$ & $(n)$ & $(\%)$ \\
\hline Fraction I & 336 & 58 & 17 & 192 & 57 & 58 & 17 & 22 & 6.5 \\
\hline Fraction II & 768 & 369 & 48 & 55 & 7 & 265 & 35 & 51 & 6.6 \\
\hline Total & 1104 & \multicolumn{8}{|c|}{ Overall response: $1070(97 \%)$. } \\
\hline
\end{tabular}

Fraction I = cells obtained using only enzymatic digestion. Fraction II = cells obtained by enzymatic pretreatment followed by mechanical loosening. $\mathrm{CK}$ pattern $=$ contraction upon stimulation, enhanced contraction after stimulus is switched off; CR pattern = contraction upon stimulation, relaxation after stimulus is switched off; miscellaneous patterns $=$ cells showing loss of internal material or explosion during contraction, contraction into a globular form or elongation upon stimulation. Shortening, but by less than $5 \%$ of initial length = cells responding according to the CK or CR pattern but shortening less than $5 \%$ of initial length.

In all responding cells the following variables were measured: initial length, before the start of the stimulation; latency time, from the beginning of stimulation until the first visible movement; contraction time, from the moment of first movement until maximum shortening; relative shortened length, i.e. the length at maximum shortening, shown as a percentage of the initial length and shortening velocity, the quotient of absolute shortening and contraction time.

To avoid large errors in variables such as the relative shortening and the unloaded shortening velocity, cells that showed a relative change in length

Table 4. Differences between variables from cells showing the same reaction pattern (CK or CR) and originating from the same fraction (I or II), but stimulated with pulses of different duration $(5.0 \mathrm{~ms}, 10.0 \mathrm{~ms}$ or $15.0 \mathrm{~ms})$.

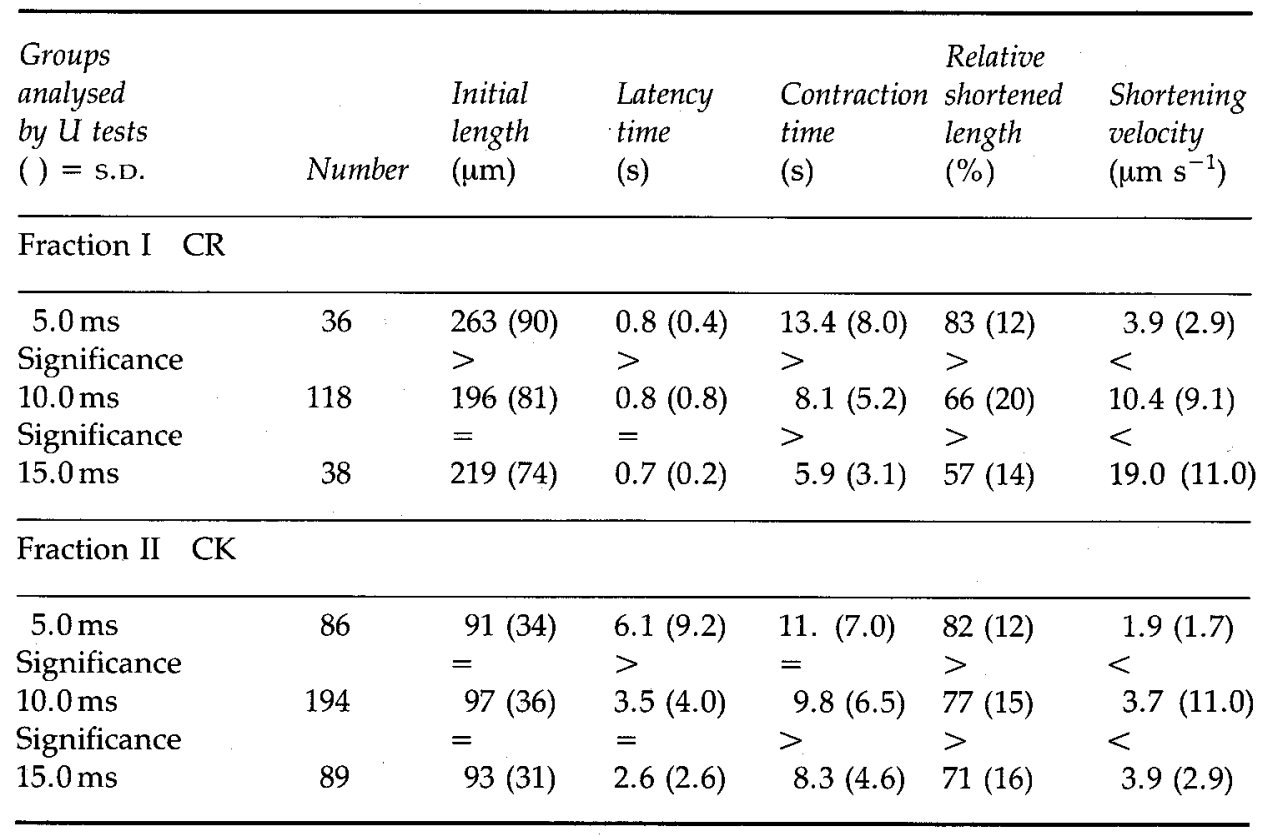

In every case the repetition frequency was $50 \mathrm{~Hz}$ and the voltage was $1.8 \mathrm{~V}$. Significance according to the Mann-Whitney U-test at the $5 \%$ level is indicated with < or $>$ sign; = indicates no significant difference. Values of variables are shown as averages (standard deviation). 
of less than $5 \%$ on stimulation were excluded from further analysis (see Table 3). Also the cells showing miscellaneous reaction patterns were excluded from further analysis.

Analysis of variance showed that, in most cases, particularly those from Fraction I experiments, there was no significant variation between variables measured in corresponding groups from different experiments. Therefore corresponding data were combined and jointly analysed.

Cells from Fraction I showed a rather flat distribution of initial lengths, whereas the distribution of initial length of the Fraction II cells was almost normal, though somewhat skewed to the shorter lengths.

Non-parametric correlation tests demonstrated a strong correlation (Spearman's rank correlation coefficient about 0.8) between initial length and length at maximum shortening, but the correlation between initial length and absolute shortening, although significant, was only about 0.4. The correlation between relative shortening and initial length was marginal $(0.05<P<0.10)$, suggesting that the relative shortening is more or less constant over the total initial length range.

The experiments with pulses of different duration $(5.0,10.0$ and $15.0 \mathrm{~ms})$ showed that pulses of longer duration yielded shorter latency and contraction times, greater relative shortening and a higher velocity of shortening. In most cases these differences were statistically significant (see Table 4 ).

The further analyses presented in this paper are based on the experiments using a pulse duration of $10.0 \mathrm{~ms}$, which form the majority of all experiments performed.
Table 5 shows that cells showing the $C K$ pattern tended to shorten to a lesser degree and more slowly than cells showing the $C R$ pattern.

Table 6 shows that cells in Fraction I preparations generally shortened more quickly, with shorter latency and contraction times, than cells from Fraction II preparations. The differences in latency and contraction times were more pronounced in CK cells, whereas $\mathrm{CR}$ cells showed a larger difference in shortening velocity and also showed a much larger initial length in Fraction I preparations.

\section{Discussion}

Since the pig bladder contains substantial amounts of dense connective tissue structures in the form of collagen, elastin and reticulin, it makes severe demands on any method for isolating viable single cells. Rather aggressive enzymes and/or long incubation times are necessary and this means that the cells may be damaged by toxic remnants in the enzyme preparation, or by deviations of the $\mathrm{pH}$ from the physiological range caused by the products of enzymatic digestion. To minimize such damage an efficient enzyme system and a high-capacity buffer system are needed. These were ultimately found in the form of Worthington's Collagenase CLS IV, which is not a very highly purified enzyme preparation, and a high-concentration Hepes buffer. The Hepes buffer eliminated the need for inconvenient $\mathrm{pH}$ adjustments (Obara, 1984) or for vigorous bubbling with $\mathrm{CO}_{2}$, which damages the cells. During the development of the method, a number of published isolation methods (Chamley-Campbell et al., 1979; Ishii \& Takahashi, 1982; Thüroff et al., 1982,

Table 5. Differences between variables estimated for cells reacting with either the CK or the $C R$ pattern, as a response to stimulation with $1.8 \mathrm{~V}, 10.0 \mathrm{~ms}$ pulses at a repetition frequency of $50 \mathrm{~Hz}$, for both Fractions I and II.

\begin{tabular}{|c|c|c|c|c|c|c|}
\hline $\begin{array}{l}\text { Groups } \\
\text { analysed } \\
\text { by U test } \\
()=\text { s.D. }\end{array}$ & Number & $\begin{array}{l}\text { Initial } \\
\text { length } \\
(\mu \mathrm{m})\end{array}$ & $\begin{array}{l}\text { Latency } \\
\text { time } \\
\text { (s) }\end{array}$ & $\begin{array}{l}\text { Contraction } \\
\text { time } \\
\text { (s) }\end{array}$ & $\begin{array}{l}\text { Relative } \\
\text { shortened } \\
\text { length } \\
(\%)\end{array}$ & $\begin{array}{l}\text { Shortening } \\
\text { velocity } \\
\left(\mu \mathrm{m} \mathrm{s}^{-1}\right)\end{array}$ \\
\hline \multicolumn{7}{|l|}{ Fraction I } \\
\hline $10.0 \mathrm{~ms} \quad \mathrm{CK}$ & 49 & $104(51)$ & $2.5(3.9)$ & $7.3(4.5)$ & 79 (11) & $3.5(2.4)$ \\
\hline Significance & & & & & & $<$ \\
\hline $10.0 \mathrm{~ms} \quad \mathrm{CR}$ & 118 & $196(81)$ & $0.8(0.8)$ & $8.1(5.2)$ & $66(20)$ & $10.4(9.1)$ \\
\hline \multicolumn{7}{|l|}{ Fraction II } \\
\hline $10.0 \mathrm{~ms} \quad \mathrm{CK}$ & 194 & $97(36)$ & $3.5(4.0)$ & $9.8(6.5)$ & $77(15)$ & $3.7(11)$ \\
\hline Significance & & $=$ & $=$ & $=$ & & $<$ \\
\hline $10.0 \mathrm{~ms} \quad \mathrm{CR}$ & 26 & $116(26)$ & $2.4(3.0)$ & $9.0(4.4)$ & $68(15)$ & $5.4(5.1)$ \\
\hline
\end{tabular}

Significance according to the Mann-Whitney U-test at the $5 \%$ level is indicated with $<$ or $>$ sign; = indicates no significant difference. Values of variables shown as averages (standard deviation). 
Table 6. Differences between variables from cells showing the same reaction pattern as a result of the same stimulus, but originating from the two differently isolated fractions.

\begin{tabular}{|c|c|c|c|c|c|c|}
\hline $\begin{array}{l}\text { Groups } \\
\text { analysed } \\
\text { by U test } \\
()=\mathrm{s} . \mathrm{D} . \\
10.0 \mathrm{~ms}, \mathrm{CK}\end{array}$ & Number & $\begin{array}{l}\text { Initial } \\
\text { length } \\
(\mu \mathrm{m})\end{array}$ & $\begin{array}{l}\text { Latency } \\
\text { time } \\
\text { (s) }\end{array}$ & $\begin{array}{l}\text { Contraction } \\
\text { time } \\
\text { (s) }\end{array}$ & $\begin{array}{l}\text { Relative } \\
\text { shortened } \\
\text { length } \\
(\%)\end{array}$ & $\begin{array}{l}\text { Shortening } \\
\text { velocity } \\
\left(\mu \mathrm{m} \mathrm{s}^{-1}\right)\end{array}$ \\
\hline $\begin{array}{l}\text { Fraction I } \\
\text { Significance } \\
\text { Fraction II }\end{array}$ & $\begin{array}{r}49 \\
194\end{array}$ & $\begin{array}{l}104(51) \\
= \\
97(36)\end{array}$ & $\begin{array}{l}2.5(3.9) \\
< \\
3.5(4.0)\end{array}$ & $\begin{array}{l}7.3(4.5) \\
< \\
9.8(6.5)\end{array}$ & $\begin{array}{l}79(11) \\
= \\
77(15)\end{array}$ & $\begin{array}{l}3.5(2.4) \\
3.7(11)\end{array}$ \\
\hline $10.0 \mathrm{~ms}, \quad \mathrm{CR}$ & & & & & & \\
\hline $\begin{array}{l}\text { Fraction I } \\
\text { Significance } \\
\text { Fraction II }\end{array}$ & $\begin{array}{r}118 \\
26\end{array}$ & $\begin{array}{l}196(81) \\
> \\
116(72)\end{array}$ & $\begin{array}{l}0.8(0.8) \\
= \\
2.4(3.0)\end{array}$ & $\begin{array}{l}8.1(5.2) \\
= \\
9.0(4.4)\end{array}$ & $\begin{array}{l}66(20) \\
= \\
68(15)\end{array}$ & $\begin{array}{l}10.4(9.1) \\
> \\
5.4(5.1)\end{array}$ \\
\hline
\end{tabular}

Significance according to the Mann-Whitney U-test at the $5 \%$ level is indicated with < or > sign; = indicates no significant difference. Values of variables shown as averages (standard deviation).

1983; van Dijk et al., 1984) were tried without success. Although some of these methods resulted in reasonable cell yields, with Trypan Blue tests showing up to $95 \%$ exclusion, none of the preparations showed any form of contractile reaction on pharmacological or electrical stimulation. Contractility thus seems to be a more stringent requirement than Trypan Blue exclusion, and so it was used as a measure of the quality of the preparation during the further development of the method.

In order to test the contractility of individual cells in a reproducible manner, electrical stimulation was used. During the first trials fouling of the electrode by organic materials attracted by electrophoretic forces, posed a troublesome problem, which was overcome by diluting the original incubation fluid (MEM with $10 \%$ FCS) with twice its volume of Krebs-Hepes buffer (fluid D in Table 1). This resulted in a lower organic content, without removing all nourishment for the cells. A voltage of $1.8 \mathrm{~V}$ proved to be the maximum level at which, with the combination of platinum and silver electrodes used in these studies, effective stimulation was possible without eliciting electrolysis near the electrodes. Cells could be stimulated repeatedly to contract, thus showing that the shortening observed represented a physiological contractile response.

The isolation method described in this paper yields contractile cells which can be used continuously for at least 12 hours without loss of contractility or viability. In pilot experiments, contractile cells isolated in this way were cultured successfully, but the contractile properties were lost within the first few culture generations (Chamley-Campbell \& Campbell, 1981). However, preparations can easily be preserved for use in later experiments, e.g. on the next day, without noticeable loss of contractile properties, by storage in closed plastic tubes or vessels in a vibration-free refrigerator at $4^{\circ} \mathrm{C}$. Cooling may even have a relaxing effect on the cells, as is indicated by the significantly longer initial length found in the Fraction I preparations (see Table 6), which were kept in the refrigerator for at least 6 hours before testing. A possible alternative explanation for the different initial cell lengths observed in preparations from Fractions I and II is that Fraction II cells may already be in a partially contracted state induced by the relatively large forces used to loosen them mechanically.

Inspection of slides of Bouin-fixed Gomori-stained unstretched and unstimulated pig bladder material (the same as used for the isolations) suggested that, in adequately isolated preparations, the minimum cell length should be at least $80-100 \mu \mathrm{m}$. This criterion was met by both our cell preparations (see Table 4).

Comparison of all aspects of Fractions I and II suggests that Fraction I preparations are, for both CK and CR groups, superior to Fraction II preparations for the following reasons:

(1) In general Fraction I shows significantly longer initial cell lengths than Fraction II (see Table 6 for $10.0 \mathrm{~ms}$ groups).

(2) Fraction I tends to show shorter latency and contraction times (see Table 6).

(3) Fraction I cells contract with higher velocities (see Table 6), and the values are closer to those 
published in the literature for other types of smooth-muscle cells (Bagby, 1974; Murphy, 1976; Small, 1977).

(4) Fraction I preparations contain a far higher percentage of cells responding to stimulation with the CR pattern than Fraction II preparations (see Table 3 ).

The CK or off-response pattern has been stated to occur in various kinds of smooth-muscle preparations, usually involving nerve stimulation (strips or organs) (De Carle et al., 1977; Fox \& Daniel, 1979; Papasova et al., 1981; Hong et al. 1985). We believe, however, that for single cells it is a less physiological response than the $C R$ pattern for the following reasons:

(1) Cells showing the CK pattern have a significantly smaller initial length than cells showing the $C R$ pattern, possibly indicating contraction caused by mechanical manipulation and/or by ionic leakage following cell wall damage.

(2) Cells responding with the CK pattern show longer latency and contraction times, a smaller degree of shortening and a lower contraction velocity than those responding with the CR pattern (see Table 5).

In the literature dealing with the smooth muscle of the urinary bladder, there is an ongoing discussion about the pathways via which electrical field stimulation of bladder strips in vitro leads to contraction and whether direct stimulation of the cells is possible (Cowan \& Daniel, 1982; Sjogren et al., 1982; Sibley, 1984; Kinder \& Mundy, 1985). In this series of experiments, we have shown that single cells contract in response to direct electrical stimulation, provided that the pulse duration is $5.0 \mathrm{~ms}$ or longer, and this implies that direct stimulation of bladder strips should be possible.

The dependence of responses on pulse duration (see Table 4) shows a general pattern of improvement in the latency time, the contraction time, the relative shortened length and the shortening velocity as the pulse duration is increased from 5.0 to $15.0 \mathrm{~ms}$. This indicates that the responses obtained represent a physiological contraction and not a destructive electrocoagulation phenomenon. Moreover, repeated stimulation leads to repetition of the response.

Our conclusions may be summarized as follows.

The method that has been described for isolating smooth-muscle cells from pig bladders is simple and suitable for routine experimental use. It gives a satisfactory yield of cells with reproducible properties, especially when the Fraction I preparation is used.

Cells obtained with this method are ready for use in mechanical, electrophysiological or pharmacological experiments, and a sufficient number of viable cells is available for at least 12 hours after isolation.
Furthermore, the cells can be stored without deterioration.

Factors influencing the viability and ultimately the contractile properties of the isolated cells are: the toxic contaminants remaining in the enzyme preparations, the $\mathrm{pH}$ and the amount of mechanical manipulations carried out in isolating the cells.

Direct electrical stimulation of single smoothmuscle cells from pig bladders has been shown to be possible. The consistent dependence of the contractile responses on the stimulus parameters demonstrates the validity of the stimulation experiments and the results obtained. If bladder strips are stimulated electrically with adequate stimuli, at least part of the response must be due to direct stimulation of the cells.

\section{Acknowledgements}

We are grateful to the Department of Physiology and Physiological Physics (J. A. E. Spaan), University of Leiden, The Netherlands, for helpful suggestions and for providing us with a cell incubator and micromanipulators.

\section{Appendix}

List of chemicals, enzymes and additives.

Albumin, Bovine, Fraction V, No. A-4503, Sigma Chemical Company.

Antitrypsin, from chicken egg white, type II-O, No. T-9253, Sigma Chemical Company.

Collagenase, CLS IV, $160 \mathrm{U} \mathrm{mg}^{-1}$, Worthington Diagnostic Systems Inc.

Deoxyribonuclease 1, from Beef Pancreas, $410 \mathrm{Kunitz}$ Units/mg, No. DN-25, Sigma Chemical Company. FCS, Foetal Calf Serum, B 97140-308-3, Commonwealth Serum Laboratories, Melbourne, Australia.

Hepes, 4-(2-Hydroxyethyl)-1-piperazine-ethanesulphonic acid, No. H-3375, Sigma Chemical Company. Klearol, Witco Chemical B.V. (Sonneborn Division), Haarlem, The Netherlands.

Krebs buffer: standard stock solution derived without D-glucose, made out of first-grade components, pharmaceutical department, Dykzigt Academic Hospital, Rotterdam, The Netherlands.

MEM, Earle's Salts, dry powdered medium, Cat. No. 072-1100, Gibco Europe BV, The Netherlands.

Tables 1 and 2 show the composition of the fluids and reagents used for transport, isolation and experiments. All fluids shown in Table 1 were sterilized by filtration and stored at $4^{\circ} \mathrm{C}$. Foetal calf serum was added sterilely to the MEM solution in a $10 \%(\mathrm{v} / \mathrm{v})$ concentration. 


\section{References}

BAGBY, R. M. (1974) Time course of isotonic contraction in single cells and muscle strips from Bufo marinus stomach. Am. J. Physiol. 227, 789-93.

CARLE, D. J. de, CHRISTENSEN, J., SZABO, A. C., TEMPLEMAN, D. C. \& MCKINLEY, D. R. (1977) Calcium dependence of neuromuscular event in esophageal smooth muscle of the opossum. Am. J. Physiol.232, E547-52.

CHAMLEY-CAMPBELL, J. H \& CAMPBELL, G. R. (1981) What controls smooth muscle phenotype? Atherosclerosis 40, 347-57.

CHAMLEY-CAMPBELL, J., CAMPBELL, G. R. \& ROSS, R. (1979) The smooth muscle cell in culture. Physiol. Rev. 59, 1-42.

COWAN, W. D. \& DANIEL, E. E. (1983) Human female bladder and its noncholinergic contractile function. Can. J. Physiol. Pharmacol. 61, 1236-46.

DOUGLAS, W. R. (1972) Of pigs and men and research. Space Life Sci. 3, 226-34.

DUYL, W. A. van (1985) Spontaneous contractions in urinary bladder smooth muscle: Preliminary results. Neurol. Urodyn. 4, 301-7.

DIJK, A. M. van, WIERINGA, P. A., MEER, M. van der \& LAIRD, J. D. (1984) Mechanics of resting isolated single vascular smooth muscle cells from bovine coronary artery. Am. J. Physiol. 246 (Cell Physiol. 15), C277-C287.

FAY, F. S. (1977) Isometric contractile properties of single isolated smooth muscle cells. Nature, Lond. 265, 553-6.

FAY, F. S., COOKE, P. H. \& CANADY, P. G. (1976) Contractile properties of isolated smooth muscle cells. In Physiology of Smooth Muscle (edited by BULBRING, E. and SHUBA, M. F.), pp. 249-64. New York: Raven Press.

FOX, J. A. \& DANIEL, E. E. (1979) Role of $\mathrm{Ca}^{2+}$ in genesis of lower esophageal sphincter tone and other active contractions. Am. J. Physiol. 237, E163-71.

GLERUM, J. J., PINO, E. A. \& MASTRIGT, R. van (1986) A low cost computer-controlled asynchronous-video cross-hair device. Med. Biol. Eng. Comput. Submitted for publication.

HELLSTRAND, P. (1979) Mechanical and metabolic properties related to contraction in smooth muscle. Acta Physiol. Scand. Suppl. 464, 1-54.

HONG, K. W., BIANCANI, P. \& WEISS, R. M. (1985) 'On' and 'Off' responses of guinea pig ureter. Am. J. Physiol. 248, C165-9.

INCE, C., YPEY, D. L., DIESSELHOFF-DEN DULK, M. M. C., VISSER, J. A. M., VOS, A. de \& FURTH, R. van. (1983)
Micro- $\mathrm{CO}_{2}$-incubator for use on a microscope. $J$. Immun. Meth. 60, 269-75.

ISHII, N. \& TAKAHASHI, K. (1982) Length-tension relation of single smooth muscle cells isolated from the pedal retractor muscle of Mytilus edulis. J. Musc. Res. Cell Motility 3, 25-38.

KINDER, R. B. \& MUNDY, A. R. (1985) Atropine blockade of nerve-mediated stimulation of the human detrusor. $\mathrm{Br}$. J. Urol. 57, 418-21.

MASTRIGT, R. van \& GLERUM, J. J. (1985a) Electrical stimulation of smooth muscle strips from the urinary bladder of the pig. J. biomed. Eng.7, 2-8.

MASTRIGT, R. van \& GLERUM, J. J. (1985b) In vitro comparison of isometric and stop-test contractility parameters for the urinary bladder. Urol Res. 13, 11-17.

MASTRIGT, R. van \& GRIFFITHS, D. J. (1979) Contractility of the urinary bladder. Urol. Int. 34, 410-20.

MASTRIGT, R. van \& GRIFFITHS, D. J. (1986) An evaluation of contractility parameters determined from isometric contractions and micturition studies. Urol. Res. 14, 45-52.

MEISS, R. A. (1975) Graded activation in rabbit mesotubarium smooth muscle. Am. J. Physiol. 229, 455-65.

MURPHY, R. A. (1976) Contractile system function in mammalian smooth muscle. Blood Vessels, 13, 1-13.

OBARA, K. (1984) Isolation and contractile properties of single smooth muscle cells from guinea pig taenia caeci. Jap. J. Physiol. 34, 41-54.

PAPASOVA, M., GACHILOVA, S. \& MIZHORKOVA, z. (1981) Analysis of the innervation of the gastroduodenal region. Acta Physiol. Pharmacol. Bulg. 7, 3-9.

SIBLEY, G. N. A. (1984) A comparison of spontaneous and nerve-mediated activity in bladder muscle from man, pig and rabbit. J. Physiol., Lond. 354, 431-43.

SJOGREN, C., ANDERSSON, K., HUSTED, S., MATTIASSON, A. \& MOLLER-MADSEN, B. (1982) Atropine resistance of transmurally stimulated isolated human bladder muscle. J. Urol. 128, 1368-71.

SMALL, J. V. (1977) Studies on isolated smooth muscle cells: The contractile apparatus. J. Cell Sci. 24, 327-49.

THÜROFF, J. W., BAZEED, M. A., SCHMIDT, R. A., LUU, D. J. \& TANAGHO, E. A. (1983) Cultured rabbit vesical smooth muscle cells for lining of dissolvable synthetic prosthesis. Urology, 21, 155-8.

THÜROFF, J. W., BAZEED, M. A., SCHMIDT, R. A. \& TANAGHO, E. A. (1982) Drug-induced responses of canine vesical smooth muscle cells in cultures. Neurol. Urodyn. 1, 233-8. 